\title{
Screening of Penaeus vannamei Boone, 1931 collected from east coast of India for monodon baculovirus (MBV) and hepatopancreatic parvovirus (HPV)
}

\author{
V. JAGADEESAN, P. EZHIL PRAVEENA, T. BHUVANESWARI, K. P. JITHENDRAN \\ AND S. K. OTTA \\ ICAR-Central Institute of Brackishwater Aquaculture, 75, Santhome High Road, R. A. Puram, Chennai - 600028 \\ Tamil Nadu, India \\ e-mail: epraveena@ciba.res.in
}

\begin{abstract}
Aquaculture is one of the fastest growing sectors yielding more than $10 \%$ growth rate per annum over the past 10 years, with a contribution of about $16 \%$ of animal protein production globally. Aquaculture production has surpassed that of the other meat producing sectors. Diseases, especially of viral etiology, remains a stumbling block for the growth of this sector posing great threat. The major viruses affecting shrimps in India are white spot syndrome virus (WSSV) and infectious hypodermal hematopoietic necrosis virus (IHHNV). Besides this, monodon baculovirus (MBV) and hepatopancreatic parvovirus (HPV) also cause considerable loss to the shrimp farmers. MBV outbreaks can cause mass mortalities when combined with other viral diseases. Moreover, MBV and HPV infections can lead to slow growth in cultured penaeid shrimps, thereby affecting the production. Although studies pertaining to the prevalence of these two viruses in the tiger shrimp Penaeus monodon have been reported extensively, similar information on Penaeus vannamei farming is scanty. Hence a pilot study was undertaken to screen $P$. vannamei samples collected from various farms of Tamil Nadu, Andhra Pradesh and West Bengal. Shrimp samples ( $\mathrm{n}=20)$ from six farms during 35-75 days of culture (DOC) were collected for screening by PCR. It was found that all the samples were negative for MBV and HPV. It could be concluded that the prevalence of both these viruses in P. vannamei are either absent or very low.
\end{abstract}

Keywords: Hepatopancreatic parvovirus, Monodon baculovirus, Penaeus vannamei, Prevalence

One of the fastest growing industries in the food sector in the recent decades is aquaculture, which is capable of meeting the majority of protein requirement of food. Shrimp cultivation is one of the aquaculture segments that gives major boost to our economy. In the recent years, aquaculture sector is challenged by numerous constraints and foremost among them being diseases caused by various etiologies like viruses, bacteria and others. In shrimps, various viruses cause a number of diseases and their effects on different species also vary. One such disease is monodon baculovirus (MBV), which has been reported to cause mortality in Penaeus monodon. In addition to mortality, the pathogen is also responsible for causing slow growth in cultured penaeid shrimps thereby affecting the production. The influence of this virus on Penaeus vannamei is scanty in literature. Traditional method of MBV diagnosis is mainly through the demonstration of the occlusion bodies seen in the anterior midgut epithelium and hepatopancreatic cells by light microscopy (Lightner and Redman, 1998). Similarly, hepatopancreatic parvovirus (HPV) infection in cultured shrimp has been linked to chronic mortalities during the early larval or post-larval stages and it may result in stunted growth during the early juvenile stages (OIE, 2007). HPV is also diagnosed by the presence of inclusion bodies in the hepatopancreatic epithelial cells using light microscopy. These traditional methods of diagnosis have limited sensitivity and demonstration of occlusion/inclusion bodies requires a high level of infection. Considering these factors, the present study employed molecular techniques for screening for MBV and HPV in farmed $P$. vannamei in the east coast of India.

Shrimp samples $(n=20)$ were collected from six $P$. vannamei farms from three states of India (Tamil Nadu, Andhra Pradesh and West Bengal) and the sample details are given in Table 1. The samples were collected and preserved in $90 \%$ ethyl alcohol. For screening of shrimp samples by PCR, the hepatopancreas was excised from each sample and total DNA was extracted as per the method described by Laird et al. (1991). The extracted DNA was then tested for its purity and quantity in Nano Spectrophotometer (Implen, Germany) at $260 \mathrm{~nm}$. The extracted DNA was then subjected to PCR amplification in a thermal cycler (Applied biosystems, Singapore). The cycling conditions for $\mathrm{MBV}$ detection for first step was $96^{\circ} \mathrm{C}$ for $5 \mathrm{~min} ; 40$ cycles of $94^{\circ} \mathrm{C}$ for $30 \mathrm{sec}$, $65^{\circ} \mathrm{C}$ for $30 \mathrm{sec}, 72^{\circ} \mathrm{C}$ for $60 \mathrm{sec}$; and one cycle of $72^{\circ} \mathrm{C}$ for 
Table 1. Details of shrimp samples collected from different locations

\begin{tabular}{lll}
\hline State & District & No. of samples \\
\hline Tamil Nadu & Nagapattinam & 4 \\
& Cuddalore & 1 \\
\hline Andhra Pradesh & Thiruvarur & 1 \\
& Vijayawada & 4 \\
& Guntur & 2 \\
\hline West Bengal & Kakadwip & 8 \\
& (South 24 Parganas) & \\
\hline Total & & 20
\end{tabular}

7 min. In nested PCR for the detection of MBV, the cycling conditions were, $96^{\circ} \mathrm{C}$ for $5 \mathrm{~min} ; 35$ cycles of $94^{\circ} \mathrm{C}$ for $30 \mathrm{sec}, 60^{\circ} \mathrm{C}$ for $30 \mathrm{sec}, 72^{\circ} \mathrm{C}$ for $60 \mathrm{sec}$; and $72^{\circ} \mathrm{C}$ for $7 \mathrm{~min}$. The cycling conditions for $\mathrm{HPV}$ detection were $95^{\circ} \mathrm{C}$ for $5 \mathrm{~min} ; 35$ cycles of $95^{\circ} \mathrm{C}$ for $30 \mathrm{sec}, 60^{\circ} \mathrm{C}$ for $40 \mathrm{sec}, 72^{\circ} \mathrm{C}$ for $60 \mathrm{sec}$; and one cycle of $72^{\circ} \mathrm{C}$ for $5 \mathrm{~min}$. The amplified PCR products were resolved in $1.5 \%$ agarose gel and stained with $0.5 \mu \mathrm{g} \mathrm{ml}^{-1}$ ethidium bromide to visualise the band patterns.

For detection of MBV, the primer pair (F:5'CGATTCCATATCGGCCGAATA-3' and R:5'-TTGGCAT GCACTCCCTGAGAT-3') as reported by Belcher and Young (1998) was used, with expected product size of $533 \mathrm{bp}$. Further, the nested PCR assay was performed using the primers F:5'-TCCAATCGCGTCTGCGATACT-3' and R:5'-CGCTAATGGGGCACAAGTCTC-3', yielding a product of $361 \mathrm{bp}$. Similarly, for HPV, the primer pair (F: 5'-GCATTACAAGAGCCAAGCAG-3' and R: 5'-ACAC TCAGCCTCTACCTTGT-3'), specified by OIE (2007) with expected product size of $441 \mathrm{bp}$ was used.

Mortalities due to MBV were commonly observed in Penaeus monodon in India but perusal of the previous research literature could not reveal MBV outbreaks in P. vannamei. Ramasamy et al. (1995) reported that prevalence of MBV was $81 \%$ in post-larval $P$. monodon. They further added that the prevalence of MBV fluctuated between 68 and $92 \%$ in the different size classes of post-larval P. monodon. The mortality rate in MBV infected populations of post-larval P. monodon was $90 \%$ and ranged from 82 to $89 \%$. To elucidate whether MBV virus has any impact on the farming of $P$. vannamei this study was designed to screen P. vannamei samples collected from various farms of Tamil Nadu, Andhra Pradesh and West Bengal. During sampling undertaken during 35-75 DOC, some of the farms had the history of slow growth. The results indicated that all the 20 samples tested were negative for MBV infection by first and second step PCR (Fig. 1). Bahari et al. (2015) reported that MBV can cause mortality and histopathological changes in P. vannamei, particularly in late PL and young stages and

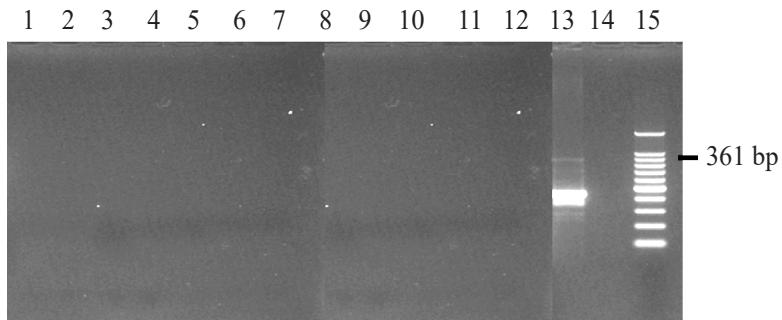

Fig. 1. Agarose gel electrophoresis for detection of MBV using nested PCR

Lane 1-12: Field samples, Lane 13: Positive control, Lane 14: Negative control, Lane 15: DNA ladder

confirmed that it could be pathogenic in P. vannamei, which is the main species of shrimp cultured in Iran. Lightner et al. (1983) reported that MBV causes serious disease in hatchery reared larval, post-larval and early juvenile stages of $P$. monodon. A single occurrence of MBV infection has been reported from Ecuador in $P$. vannamei co-cultured with P. monodon which had a high prevalence of MBV (Sindermann and Lightner, 1988). Similarly, on screening 20 samples for HPV infection, all the samples were found negative (Fig. 2).

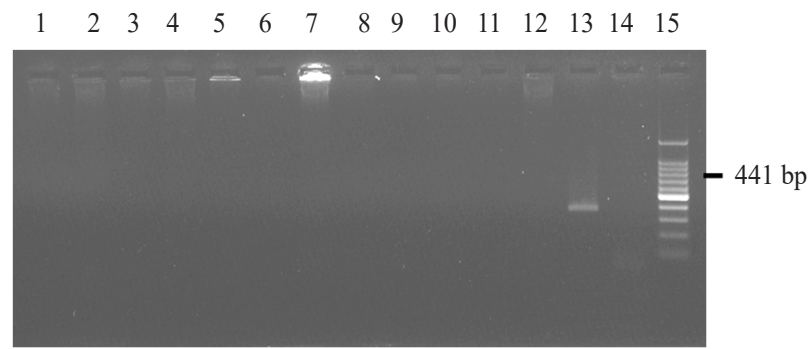

Fig. 2. Agarose gel electrophoresis for detection of HPV using PCR Lane 1-12: Field samples, Lane 13: Positive control, Lane 14: Negative control, Lane 15 : DNA ladder

Though HPV infection was reported in P. vannamei by earlier workers, our study did not get positive case of HPV infection in any of the screened samples. On perusal of literature on $\mathrm{HPV}$, it was found that only very few reports are available on P. vannamei. Manjanaik et al. (2005) found that the HPV infection was highly prevalent in wild shrimp $P$. monodon of size 5.0 to $20 \mathrm{~cm}$ in length and 6 to $80 \mathrm{~g}$ in weight. Our study, based on samplings from $P$. vannamei farms along the east coast of India did not record both the viruses MBV and HPV. Majority of the farmers culturing $P$. vannamei are using seed from SPF broodstock, which might be one of the reasons for not recording positive cases of MBV and HPV in P. vannamei during the present study. However, it is imperative that more studies and surveillance covering larger areas is required to know the prevalence of these viruses in various shrimp farms across the country. 


\section{Acknowledgements}

The authors thank the Director, ICAR-CIBA, Chennai for providing necessary facilities to carry out this work. They also thank NFDB and National Co-ordinator, NSPAAD for providing financial assistance to accomplish this work. The authors also thank Dr. A. Uma, TNFU, Chennai for providing positive control of HPV samples.

\section{References}

Bahari, A., Afsharnasab, M., Moghanjoghi, A. M., Azaritakami, G. and Shrifrohani, M. 2015. Experimental pathogenicity of shrimp, Penaeus vannamei exposed to monodon baculovirus (MBV). Iran. J. Fish. Sci., 14: 350-357.

Belcher, C. R. and Young, P. R. 1998. Colourimetric PCR-based detection of monodon baculovirus in whole Penaeus monodon post-larvae. J. Virol. Methods, 74: 21-29.

Laird, P. W., Zijdervel, A., Linders, K., Rudnicki, M. A., Jaenisch, R. and Berns, A. 1991. Simplified mammalian DNA isolation procedure. Nucleic Acids Res., 19: 4293.
Lightner, D. V., Redman, R. M. and Bell, T. A. 1983. Observations on the geographic distribution, pathogenesis and morphology of the baculovirus from Penaeus monodon Fabricius. Aquaculture, 32: 209-233.

Lightner, D. V. and Redman, R. M. 1998. Shrimp diseases and current diagnostic methods. Aquaculture, 164: 201-220.

Manjanaik, B., Umesha, K. R., Karunasagar, I. and Karunasagar, I. 2005. Detection of hepatopancreatic parvovirus (HPV) in wild shrimp from India by nested polymerase chain reaction (PCR). Dis. Aquat. Org., 63: 255-259.

OIE 2007. Aquatic Animal Disease Cards, Hepatopancreatic parvovirus disease. (http://www.oie.int/fileadmin/Home/eng/ International_Standard_Setting/docs/pdf/Hepatopancreatic Parvovirus Card 2007 Revised 92707_.pdf)

Ramasamy, P., Brennan, G. P. and Jayakumar, R. 1995. A record and prevalence of Monodon baculovirus from postlarval Penaeus monodon in Madras, India. Aquaculture, 130: 129-135.

Sindermann, C. J. and Lightner, D. V. 1988. Disease diagnosis and control in North American marine aquaculture. Elsevier, Amsterdam, 22 pp. 